\title{
Identification of Cloaca Bacteria from Candidate Releasing Chinese Alligators
}

\author{
MA Rong-rong ${ }^{1,}$ WU Xiao-bing ${ }^{1, *}$, JIANG Hong-xin², PAN Ji-hong ${ }^{1}$, \\ ZHU Jia-long ${ }^{3}$, WANG Chao-lin ${ }^{3}$ \\ (1. College of Life Sciences, Anhui Normal University, Wuhu Anhui 241000, China; \\ 2. National Wildlife Research and Development Center, State Forestry Administration, Research Institute of Forestry Ecology, Environment and \\ Protection, Chinese Academy of Forestry, Beijing 100091, China; \\ 3. Anhui Research Center for Reproduction of Chinese Alligator, Xuancheng Anhui 242000, China)
}

\begin{abstract}
The Chinese alligator (Alligator sinensis) is a critically endangered species in China. Wild populations of Chinese alligator are on the edge of extinction. Through a release program, some captive-bred alligators will be selected and released into the wild to supplement and renew natural populations. The purpose of this study was to provide data to select healthy individuals for release. Through bacteriological and molecular identification, six different genera, eight species and an unclassified bacterium were identified in 13 bacterial strains, which were isolated from the cloaca of 25 Chinese alligators. One genus and four species were identified in eight bacterial strains, which were isolated from the water where the alligators live. According to the analysis, except for the unclassified bacterium, the other bacteria from the cloaca were not pathogenic and were different from the bacteria isolated from the water. Thus, it was concluded that the 24 Chinese alligators were healthy, and could be selected to be released into the wild. As subject AS12 was identified carrying an unclassified bacteria, of which the characteristics were unknown, it was suggested that the AS12 individual not be released.
\end{abstract}

Key words: Chinese alligator (Alligator sinensis); Cloaca; Bacteria; Identification; Release

\section{野放前候选扬子鳄泄殖腔的细菌鉴定}

\author{
麻荣荣 ${ }^{1}$, 吴孝兵 ${ }^{1, *}$, 江红星 ${ }^{2}$, 潘继红 $^{1}$, 朱家龙 ${ }^{3}$, 王朝林 ${ }^{3}$ \\ (1. 安徽师范大学 生命科学学院, 安徽省重要生物资源保护与利用研究重点实验室, 安徽 芜湖 241000; \\ 2. 国家林业局 全国野生动植物研究与发展中心, 中国林业科学研究院 森林生态环境与保护研究所, 北京 100091; \\ 3. 安徽扬子鳄繁殖中心, 安徽 宣城 242000)
}

摘要: 扬子鲸(Alligator sinensis)是中国濒危的物种, 野生鳄种群已濒临灭绝。通过放归工程, 将挑选饲养鳄 放养到野外去扩大野生种群。本文的研究目的是通过检测扬子鳄的健康状况为扬子鳄的篎选提供依据。从 25 条准 备进行野放的扬子鳄泄殖腔中篮选出 13 种形态不同的菌株。应用细菌学和分子生物学方法, 鉴定它们分别属于 6 个属的 8 个种和一个未分类的菌; 从扬子鳄生活的水体中篮选出 8 种形态不同的菌株, 鉴定它们分别属于 1 个属 的 4 个种。经分析, 除了未分类的菌之外，从扬子鳄泄殖腔中分离得到的菌株都是非致病性的且不同于扬子鳄生 活水体中分离的菌株, 因此可以认为这些扬子鳄是健康的, 可以野放。由于从标记为 AS12 的扬子鳄体内分离到 一个分类地位尚未确定的菌, 对它的生理生化特征进行了检测, 但这种菌的致病性方面特征尚不清楚, 建议不考 虑野放标记为 AS12 的扬子鳄个体。

关键词: 扬子鳄; 泄殖腔; 细菌; 鉴定; 野放

中图分类号: Q959.64; Q16; Q93.331 文献标识码: A 文章编号: 0254-5853-(2008)03-0253-07

Received date: 2007-12-30; Accepted date: 2008-03-25

Foundation items: The National Natural Science Foundation of China (30770312); the Fund for Releasing Chinese Alligators by the State Forestry Administration; the Fund for Leading Scientist of Science and Technology in Anhui; the foundation of Key Laboratory of Biotic Environment and Ecological Safety in Anhui Province

*Corresponding author (通讯作者), E-mail: wuxb@mail.ahnu.edu.cn

收稿日期：2007-12-30; 接受日期：2008-03-25 
The Chinese alligator (Alligator sinensis) is one of the world's most endangered crocodiles. In recent years, because of fragmentation of their habitat, the effect of human urbanization and industrialization, the distribution area of the Chinese alligator has decreased rapidly. The population of wild Chinese alligators has declined sharply and been on the verge of extinction (Thorbjarnarson et al, 2002). Nowadays the total number of wild populations is less than 120 individuals in China (Ding \& Wang, 2004). In the past two decades, the breeding of captive Chinese alligators has been very successful and the captive population currently exceeds 10000 individuals at the Anhui Research Center for Chinese Alligator Reproduction (ARCCAR) (Thorbjarnarson et al, 2002; Chen et al, 2003). To better protect the Chinese alligator, the IUCN second world natural conservation union specifically passed the law "Chinese alligator protection resolution" and the State Forestry Administration (SFA) of China launched "The Project for the Conservation and Release into the wild of Chinese Alligators" in 2003. The aim of the project is to reinforce the protection of the wild alligators and expand the wild populations.

Before releasing captive animals it is important to know if these animals are healthy (Plowright, 1988; May, 1991; Woodford \& Kock, 1991; Mills, 1999; Woodford, 2000). In order to avoid the alligators introducing pathogenic bacteria into the wild environment and endangering the native wild populations, it is necessary to check the health of the candidate being released. In this paper, we used bacteriological methods to identify bacterial genera, and then used molecular biology methods to identify bacterial species. Since $16 \mathrm{~S}$ rRNA genes are ideal molecular markers for the classification of bacterial (Vandamme et al, 1996; Cai et al, 2003), it was used to detect the bacteria.

\section{Materials and methods}

\subsection{Study animals}

Twenty-five captive-bred Chinese alligators of ARCCAR were studied and sampled randomly (labeled with No.AS01-AS25 in Tab. 1), some of which would be selected and suggested to be released into the wild. Swabs were used for sampling. The entire head of the swab was inserted into the cloaca of Chinese alligators. Using gentle pressure with a circular motion, we swabbed the inside circumference of the cloaca two or three times, then inserted the swabs into the bacterial culture medium. A clean swab was prepared as a control group. Synchronously, we also collected 6 water samples (labeled with No. W1-W6 in Tab. 1) from the water environment of the alligators before release to validate whether the bacteria isolated were from the cloaca or from the water. The 25 cloaca samples were diluted. Then the cloaca samples and the 6 water samples were incubated on beef extract peptone medium at $37^{\circ} \mathrm{C}$ for 24 hours. The different types of colonies were isolated on the basis of their motility, morphology and Gram staining. Then a single colony was chosen and inoculated into medium slants at $37{ }^{\circ} \mathrm{C}$ for 24 hours for further bacteriological identification.

\subsection{Bacteriological identification}

According to the conventional method of bacteriological identification (Buchanan \& Gibbons, 1984; Wang, 1977; The Group of Bacteriology Classification of the Institute of Microbiology Chinese Academy of Sciences, 1978), 31 samples (25 cloaca samples and 6 water samples) were identified to genera.

\subsection{Identification by PCR method}

1.3.1 DNA extraction All bacterial strains were suspended in $1 \mathrm{~mL}$ volumes with $0.9 \%$ sterile sodium chloride solution. After the removal of cellular debris by centrifugation $\left(4^{\circ} \mathrm{C}, 8500 \times \mathrm{g}\right.$ for $10 \mathrm{~min}$ ) (Xia et al, 2005), the sedimentation of bacteria was prepared by re-suspension of cells in a $5 \%$ (wt/vol) solution of Chelex-100 (Bio-Rad, Hemel Hempstead, UK) 400 $\mu \mathrm{L}$, and then boiled for $10 \mathrm{~min}$, ice bath for $1 \mathrm{~min}$, centrifugation (12 000 $\times \mathrm{g}$ for $10 \mathrm{~min}$ ) at $25^{\circ} \mathrm{C}$. The supernatant was used as the source of the template DNA for PCR which was stored at $-20^{\circ} \mathrm{C}$.

1.3.2 PCR amplification A $25 \mu \mathrm{L}$ reaction mixture of PCR was run with 100ng of template DNA, $2.5 \mu \mathrm{L}$ $10 \times$ reaction Buffer, $1.0 \mu \mathrm{L} 25 \mathrm{mmol} / \mathrm{L} \mathrm{MgCl}_{2}, 0.5 \mu \mathrm{L} 10$ mmol/L dNTPs, $1 \mu \mathrm{L} 10 \mu \mathrm{mol} / \mathrm{L}$ each primer: $5^{\prime}$-TGG GGG GGT GCC TAA TAC ATG-3' and 5' -CCC GTA GGA GTC TGG ACC GTG TC-3' (Xia et al, 2005), 1U Taq DNA polymerase (Shanghai Promega Biological Products Limited), and sterile double distilled water to make up a final volume of $25 \mu \mathrm{L}$. The primers were synthesized by Shanghai Sangon Biotechnology Co. Ltd.. PCR reactions were conducted on a PTC-200 thermal cycler with the following conditions: an initial denaturation for $5 \mathrm{~min}$ at $95^{\circ} \mathrm{C}$ followed by 31 cycles of denaturation for $1 \mathrm{~min}$ at $94^{\circ} \mathrm{C}$, annealing for 50 seconds at $50-55^{\circ} \mathrm{C}$ and extending for 50 seconds at $72^{\circ} \mathrm{C}$. Finally reactions were held at $72^{\circ} \mathrm{C}$ for $10 \mathrm{~min}$. Annealing temp- 
Tab. 1 Morphological characteristics of 21 bacterial strains

\begin{tabular}{|c|c|c|c|c|c|c|c|c|c|}
\hline $\begin{array}{l}\text { No. of } \\
\text { strain }\end{array}$ & $\begin{array}{c}\text { Individual distribution } \\
\text { of Alligator sinensis/ } \\
\text { water }\end{array}$ & $\begin{array}{c}\text { Gr- } \\
\text { am } \\
\text { stain }\end{array}$ & $\begin{array}{l}\text { Individual } \\
\text { shape }\end{array}$ & Colour & Shape & Moisture & Colony size & Apophysis & Sawtooth \\
\hline 1 & AS01-AS25 & - & Bacilus & Gray & Round & Wet & Moderate & Ridgy & Nonexistent \\
\hline 2 & AS02, AS03, AS04, AS15 & + & Bacilus & Yellow & $\begin{array}{l}\text { Irregular } \\
\text { round }\end{array}$ & Moist & Relative big & Flat & Toothed \\
\hline 3 & $\begin{array}{l}\text { AS03-AS08, AS11, AS15, } \\
\text { AS22, AS23, AS24 }\end{array}$ & - & Bacilus & Milk white & Round & Moist & $\begin{array}{l}\text { Relatively } \\
\text { small }\end{array}$ & Ridgy & Nonexistent \\
\hline 4 & AS03 & - & Bacilus & Milk white & Like shell & Moist & Moderate & Ridgy & Nonexistent \\
\hline 5 & AS03 & - & Bacilus & Yellow & $\begin{array}{l}\text { Irregular } \\
\text { round }\end{array}$ & Moist & Moderate & Ridgy & Nonexistent \\
\hline 6 & AS03, AS23 & + & Bacilus & Hoariness & Flocculent & Moist & Big & Flat & Nonexistent \\
\hline 7 & AS06, AS15, AS25 & + & Bacilus & $\begin{array}{l}\text { Deep } \\
\text { yellow }\end{array}$ & Round & Moist & $\begin{array}{c}\text { Relatively } \\
\text { small }\end{array}$ & Ridgy & Nonexistent \\
\hline 8 & AS07 & + & Spherical & Milk white & Radiate & Relative dry & Big & Flat & Nonexistent \\
\hline 9 & AS9, AS10 & + & Bacilus & Gray & Round & Dry & Moderate & Flat & Nonexistent \\
\hline 10 & AS12 & - & Bacilus & Gray & Round & Relative dry & $\begin{array}{l}\text { Relatively } \\
\text { big }\end{array}$ & Ridgy & Toothed \\
\hline 11 & AS14 & - & Bacilus & Gray & Round & Dry & $\begin{array}{l}\text { Relatively } \\
\text { small }\end{array}$ & Ridgy & Nonexistent \\
\hline 12 & AS15 & - & Bacilus & $\begin{array}{l}\text { Light } \\
\text { yellow }\end{array}$ & Round & Moist & Moderate & Ridgy & Nonexistent \\
\hline 13 & AS18 & + & Bacilus & Milk white & $\begin{array}{l}\text { Irregular } \\
\text { round }\end{array}$ & Dry & Small & Flat & Toothed \\
\hline 14 & W1, W3, W4, W5, W6 & + & Bacilus & Yellowy & Round & Moist & Big & Flat & Toothed \\
\hline 15 & W1, W3, W4, W5 & + & bacilus & Milk white & Round & Moist & Moderate & Flat & Nonexistent \\
\hline 16 & $\begin{array}{l}\text { W1, W2, W3, W4, W5, } \\
\text { W6 }\end{array}$ & + & Bacilus & Yellowy & Round & Moist & $\begin{array}{l}\text { Relatively } \\
\text { small }\end{array}$ & Flat & Toothed \\
\hline 17 & W1, W3, W4, W5, W6 & + & Bacilus & Yellowy & Round & Moist & $\begin{array}{c}\text { Relatively } \\
\text { small }\end{array}$ & Flat & Toothed \\
\hline 18 & W5, W6 & + & Bacilus & Yellowy & $\begin{array}{l}\text { Irregular } \\
\text { round }\end{array}$ & Moist & Small & Flat & Toothed \\
\hline 19 & W6 & + & Bacilus & Yellowy & $\begin{array}{l}\text { Irregular } \\
\text { round }\end{array}$ & Moist & Small & Flat & Toothed \\
\hline 20 & W1 & + & Bacilus & $\begin{array}{l}\text { Trans- } \\
\text { parent }\end{array}$ & Round & Moist & $\begin{array}{l}\text { Relatively } \\
\text { small }\end{array}$ & Flat & Nonexistent \\
\hline 21 & W1 & + & Bacilus & Hoar & $\begin{array}{l}\text { Irregular } \\
\text { round }\end{array}$ & $\begin{array}{r}\text { Relative } \\
\text { moist }\end{array}$ & Big & Flat & Toothed \\
\hline
\end{tabular}

erature was changed when needed, from $50^{\circ} \mathrm{C}$ to $55^{\circ} \mathrm{C}$ to improve the quality of PCR products. The PCR products were separated by electrophoresis in $1 \%$ agarose gels. The gels were stained with ethidium bromide and photographed on a UV transilluminator (UVP Inc., USA).

1.3.3 Purifying, Sequencing and Sequences analysis PCR products were purified by PCR Cleanup Kit (Axygen, Biot, Ltd, Hangzhou, China) and sequenced with ABI 3730 (Analyzer by Shanghai Sangon Biotechnology Co., Ltd., Shanghai, China). Sequences were analyzed and assembled by using the software of
DNAStar (Version5.01) and Chromas 2.22. Then the sequences were blasted using the ClustalX 1.81 software (Thompson et al, 1997) and checked by eye. Finally, each of the sequences of bacterial strains was blasted on NCBI to identify the species of bacteria. The determined nucleotide sequences will be released in the GenBank nucleotide sequence databases with the accession numbers from EU253483 to EU253503.

1.3.4 Molecular phylogenetic analyses Prior to phylogenetic analyses of the 21 bacterial sequences, we obtained related sequences from GenBank, they were Proteus mirabilis (AY820623), Kurthia gibsonii 
(AM184261), Exiguobacterium acetylicum (DQ019167), Bacillus sphaericus (AF435435), Bacillus fusiformis (DQ333300), Swine manure bacterium (AY167939), Escherichia coli (AF076037), Aeromonas hydrophila (AM184306), Bacillus subtilis (DQ232747), Bacillus pumilus (EF010673), Bacillus megaterium (DQ904617), Bacillus marisflavi (AF483624), Bacillus flexus (DQ514312). In order to further confirm the phylogenetic relationships of the 21 bacteria, we constructed the trees based on the 16S rRNA genes with the data obtained from GenBank. Micrococcus luteus (AM911019) was used as the outgroup (Fig.1 and Fig.2). The data were subjected to two different methods of phylogenetic reconstruction: the Bayesian 3.0b4 (Ronquist \& Huelsenbeck, 2003) and the PAUP* version 4.0b10 (Swofford, 1998). For the Bayesian analyses, we used posterior probabilities as indicators of node confidence as these represent the true probabilities of the clades (Rannala \& Yang, 1996), probabilities $>95 \%$ were considered to be significant (Leaché \& Reeder, 2002). The robustness of MP tree topologies was tested using bootstrap analyses (Felsenstein, 1985), with 1000 replicates for MP (Hedges, 1992). We considered topologies with bootstrap values $>70 \%$ to be sufficiently supported, and those with values between 50 and $70 \%$ to be weakly supported (Huelsenbeck \& Hillis, 1993).

\section{Results}

In this study, a total of 21 bacterial strains were isolated, of which 13 strains were from the alligator's

Tab. 2 The results of bacteriological identification and molecular identification of 21 bacterial strains

\begin{tabular}{|c|c|c|c|c|c|c|c|c|c|c|c|c|c|c|c|c|}
\hline & & & & \multicolumn{12}{|c|}{ Bacteriological identification } & \multirow{4}{*}{$\begin{array}{l}\begin{array}{l}\text { Molecular } \\
\text { identification }\end{array} \\
\text { Identification } \\
\text { result } \\
\text { (species) }\end{array}$} \\
\hline \multirow{3}{*}{ No } & \multirow[b]{3}{*}{ C } & \multirow{2}{*}{\multicolumn{3}{|c|}{ Fermentation Glucose }} & \multirow{3}{*}{ S } & \multirow{3}{*}{ OT } & \multirow{3}{*}{ PD } & \multirow{3}{*}{ IT } & \multirow{3}{*}{ NFT } & \multirow{3}{*}{$\mathrm{CT}$} & \multirow{3}{*}{ HS } & \multirow{3}{*}{ MT } & \multirow{3}{*}{ LT } & \multirow{3}{*}{ G } & \multirow{3}{*}{$\begin{array}{c}\text { Identification result } \\
\text { (Genus) }\end{array}$} & \\
\hline & & & & & & & & & & & & & & & & \\
\hline & & FG & M & PG & & & & & & & & & & & & \\
\hline 1 & + & + & + & + & - & - & + & - & - & - & + & + & & + & Proteus & P.mirabilis \\
\hline 2 & + & - & - & - & - & - & & - & & & & & & & Kurthia & K.gibsonii \\
\hline 3 & + & + & + & + & - & - & + & - & - & - & + & + & & + & Proteus & P mirabilis \\
\hline 4 & + & + & + & + & - & - & + & - & - & - & + & + & & + & Proteus & P.mirabilis \\
\hline 5 & + & + & + & + & - & - & + & - & - & - & + & + & & + & Proteus & P.mirabilis \\
\hline 6 & + & - & - & - & - & - & + & - & & & & & - & & Kurthia & K.gibsonii \\
\hline 7 & - & + & + & - & - & & & & & & & & & & Exiguobaterium & E.acetylicum \\
\hline 8 & + & - & - & - & + & & & & & & & & & & Bacillus & B.sphaericus \\
\hline 9 & + & + & + & - & + & & - & & & & & & & & Bacillus & B.fusiformis \\
\hline 10 & + & + & + & + & - & + & & & - & & & & weak & + & Unclassified & $\begin{array}{l}\text { Swine manure } \\
\text { bacterium }\end{array}$ \\
\hline 11 & + & + & + & - & - & - & - & + & - & & - & + & + & - & Escherichia & E.coli \\
\hline 12 & + & + & - & - & - & + & & & & & & & - & & Aeromonas & A.hydrophila \\
\hline 13 & + & + & + & - & + & & & & & + & & & & & Bacillus & B.subtilis \\
\hline 14 & + & + & + & - & + & & & & & + & & & & & Bacillus & B.pumilus \\
\hline 15 & + & + & + & - & + & & + & & & + & & & & & Bacillus & B.megaterium \\
\hline 16 & + & + & + & - & + & & & & & + & & & & & Bacillus & B.pumilus \\
\hline 17 & + & + & + & - & + & & & & & + & & & & & Bacillus & B.pumilus \\
\hline 18 & + & + & + & - & + & & & & & + & & & & & Bacillus & B.pumilus \\
\hline 19 & + & + & + & - & + & & & & & & & & & & Bacillus & B.pumilus \\
\hline 20 & + & + & + & & + & & & & & & & & & & Bacillus & B.marisflavi \\
\hline 21 & + & + & + & & + & & & & & & & & & & Bacillus & B.flexus \\
\hline
\end{tabular}

No: No. of strain; C: Catalase; FG: Fermentation glucose; M: Motility; PG: Produce gas; S: Spore; OT: Oxidase test; PD: Phenylanine dehydrogenase;

IT: Indole test; NFT: Nitrogen fixing test; CT: Citrate test; HS: Hydrogen sulfide; HS: Hydrogen sulfide; MT: Methyl red test; LT: Lactose test; G: Gelatin

+: positive; -: negative; the blanks: no test; 1-13, the cloaca bacteria of Chinese alligators; 14-21, the bacteria from the habitat water. 
cloaca and 8 strains from the habitat water of the alligators. No bacteria were detected in the control group. Morphological and physiological characteristics of the 21 bacterial strains based on bacteriological method were described in Tab. 1 and Tab. 2. The results showed that the 13 strains from the alligator's cloaca belong to 8 species of 6 different genera, and an unclassified bacterium. The 8 strains from the habitat water belong to
4 species of one genus.

Sequences of $300 \mathrm{bp}$ were amplified successfully from 21 bacterial strains. By blasting on NCBI, 12 species and an unclassified bacterium from 21 bacterial strains were identified (GenBank accession Nos. EU253483 to EU253503). The phylogenetic tree showed the position of 21 bacteria (the MP tree was shown in Fig. 1 and the Bayesian tree was shown in Fig. 2).

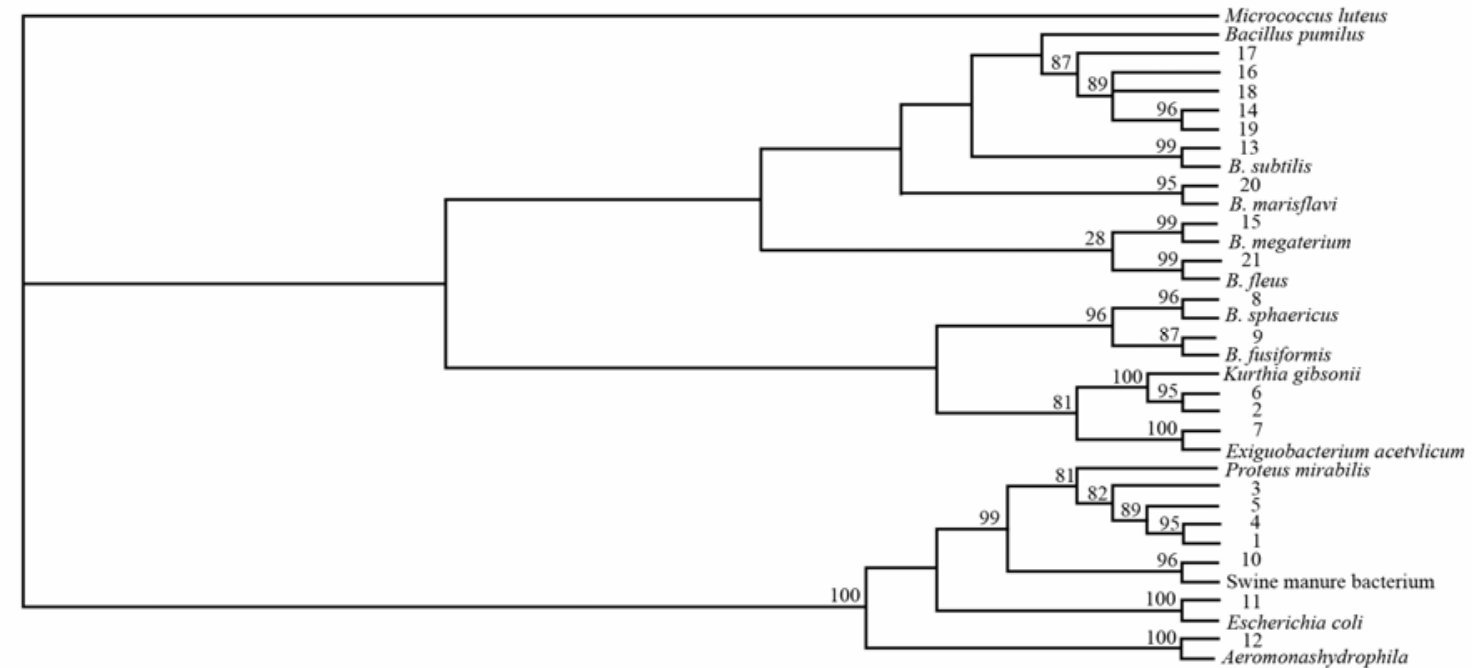

Fig. 1 MP tree of the 21 bacteria based on the 16S rRNA gene partial sequences with the confident values (bootstrap 1000) indicated above each branch

No. 1-21 in this figure was consistent with the No. of strain in Tab. 1 and Tab. 2.

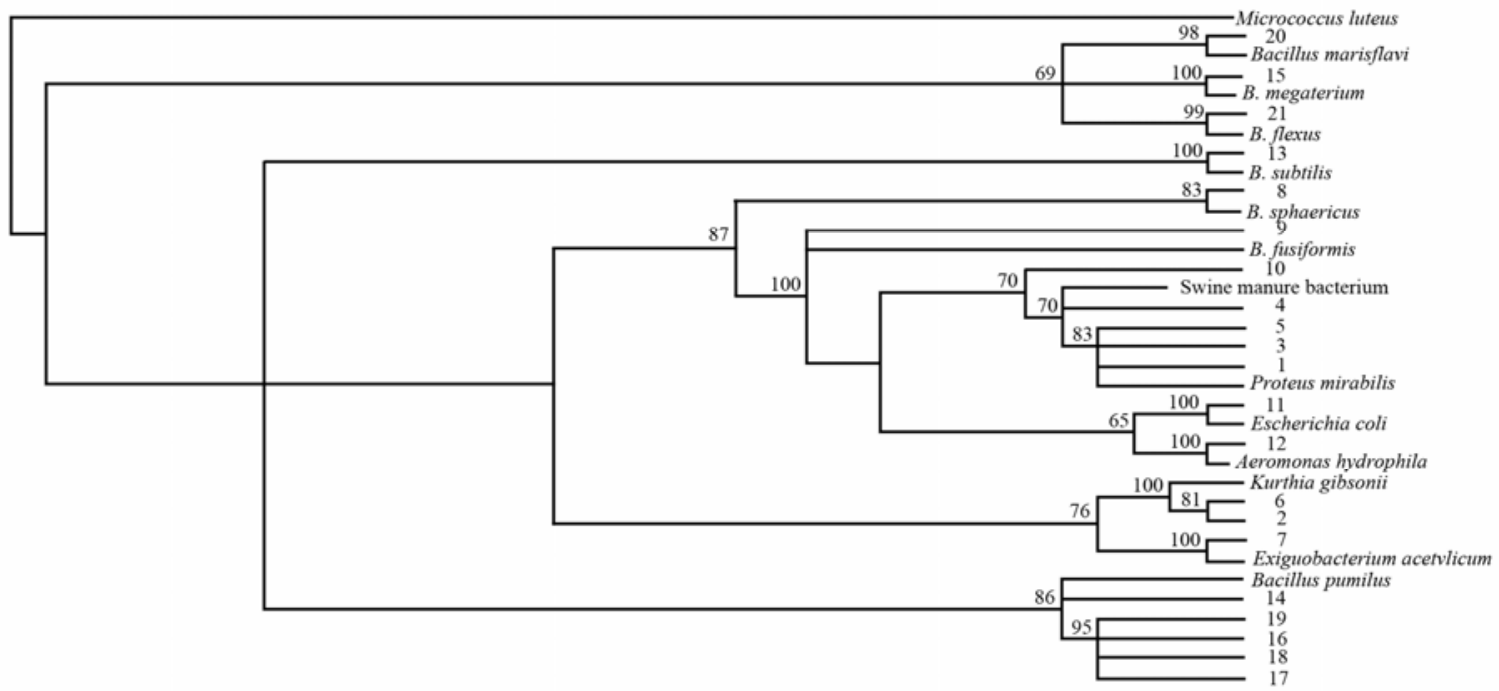

Fig. 2 Bayesian tree of the 21 bacteria based on the 16S rRNA gene partial sequences

Numbers above the nodes are Bayesian posterior probability values. No. 1-21 in this figure was consistent with the No. of strain in Tab. 1 and Tab. 2.

\section{Discussion}

Crocodiles lack bladders so intestinal content enters the inner cloaca directly (Kuchel \& Franklin, 1998). It has been reported that detecting cloacal contents could be used as a method to evaluate animal health (Hua et al, 1998; Miyamoto et al, 2000; Jaime et al, 2002; Song et al, 2005). Therefore, in this study the cloaca detection method was used as an evaluation method to check the health of Chinese alligators, for the first time. 
Bacteriological identification is a traditional method and is also inexpensive. It can provide the morphological characteristics of bacteria, so its application is wide reaching (Xu et al, 2004). But this method is limited as it is time-consuming, instability of the phenotype expression, low positive rates and low sensitivity (Jiao \& Liu, 1996). Using bacteriological methods, some bacterial characteristics are inconspicuous and the bacteria cannot be classified according to references (Buchanan \& Gibbons, 1984; Wang, 1977; The Group of Bacteriology Classify of the Institute of Microbiology Chinese Academy Science, 1978), such as No.10 bacterium isolated in this study. The application of molecular techniques in the identification of microorganisms has proved to be very useful, not only because of its sensitivity and reproducibility, but also as results can be rapidly obtained. Because different evolution rate regions of the 16S rRNA gene, it have been a molecular marker of bacterial classification. The data of 16S rRNA gene could be utilized to identify the new isolated bacteria accurately (Shen \& Feng, 2004). 16S rRNA gene as a tool for bacterial identification has been proven to be fast, accurate and therefore useful for a quick identification of the bacteria (Jones et al, 2005; Janssen, 2006). In this study, we used bacteriological methods to identify the strains of genera, and then used 16S rRNA gene markers to further identify. The results showed that PCR identification was consistent with the bacteriological identification.

Through bacteriological tests, 21 bacteria were identified to genera and by phylogenetic tree analyses, 21 bacteria were matched with the closest reference sequence in GenBank, with a high similarity.

Six genera, including 8 species and an unclassified bacterium, were found in the cloaca of Chinese alligators, but only one genus, including 4 species, were found in the water. All cloaca bacteria were classified as genera Proteus, Bacillus, Kurthia, Exiguobacterium, Escherichia and Aeromonas. In genus Bacillus, three

\section{References:}

Buchanan RE, Gibbons NE. 1984. Bergey’s Manual of Determinative Bacteriology [M]. 8nd Edition. Beijing: Beijing Science Publisher.

Cai HY, Archambault M, Gyles CL, Prescott JF. 2003. Molecular genetic methods in the veterinary clinical bacteriology laboratory: current usage and future applications [J]. Anim Health Res Rev, 4 (2): 73-93.

Chen BH, Wu XB, Hua TM, Wang CL. 2003. Research on the Chinese alligator [M]. Shanghai: Shanghai Science and Technology Press. species, B. sphaericus, B. fusiformis and B. subtilis, were isolated from the cloaca samples, and four specie, $B$. pumilus, B. megaterium, B. marisflavi and B. flexus, were from the water. Our results indicated that the bacteria from the cloaca were not isolated from the pond water.

Genera Proteus and Escherichia are common intestinal bacteria. Proteus mirabilis are found in many animal faeces and E. coli are normal flora in human and animal intestines (Wang, 1977). B. subtilis is common (Zhang \& Li, 2001). Genus Aeromonas is reported to include 14 species and belong to the family Vibrionacea (Qu, 2006). They are common hydrophilous bacteria in nature. A. hydrophila is hydrophilous bacteria distributed commonly in nature, and it is also a regular commensalism bacterium (Buchanan \& Gibbons, 1984). K.gibsoni could be isolated from normal faeces (Buchanan \& Gibbons, 1984). Kurthia's pathogenicity has not been reported in the bacterial study of Chinese alligators. The strain of Exiguobacterium was isolated from pond water (Frühling et al, 2002). Similarly its pathogenicity has not been reported in bacterial studies of Chinese alligators. From the analyses results, we can conclude that the 12 bacterial strains were not pathogenic to the health of Chinese alligators. In this study, the sequence of 16S rRNA gene sequences from the No.10 bacterium was close to a swine mature bacterium but its identity is still unknown and its pathogenicity towards animals is also unclear. Therefore, the Chinese alligator with this bacterium should not to be released as yet.

By analyzing the unclassified bacteria from the cloaca of the AS12 Chinese alligator we suggest that the AS12 individual should not to be selected for release. In this study, we advise strongly that the bacteria from the cloaca of Chinese alligators should be checked before release and reintroduction into the wild in order to avoid potential ecological harm, such as introducing pathogenic bacteria into wild populations of Chinese alligators.

Ding YZ, Wang XM. 2004. Factors influencing the population status of wild Chinese alligators (Alligator sinensis) [J]. Biodiversity Science, 12 (3): 324-332.

Felsenstein J. 1985. Confidence limits on phylogenies: an approach using the bootstrap [J]. Evolution, 39: 783-791.

Frühling A, Schumann P, Hippe H, Sträubler B, Stackebrandt E. 2002. Exiguobacterium undae sp. nov. and Exiguobacterium antarcticum sp. nov [J]. International Journal of Systematic and Evolutionary 
Microbiology, 52: 1171-1176.

Hedges SB. 1992. The number of replications needed for accurate estimation of the bootstrap P value in phylogenetic studies [J]. Mol Biol Evol, 9 (2): 366-369.

Hua YP, Li F, Gu HJ , Wang YL, Wang YL. 1998. Study on the bacteria carrying status of 11 species of wild and captive birds on Zhalong Wetland [J]. Journal of Northeast Forestry University, 26 (6): 37-43.

Huelsenbeck JP, Hillis DM. 1993. Success of phylogenetic methods in the four-taxon case [J]. Syst Biol, 42: 247-264.

Jaime P, Juan M, Pablo Y, Víctor B, Pablo GB, Susana V, Cristina B. 2002. Bacteria divert resources from growth for Magellanic penguin chicks [J]. Ecology Letters, 5 (6): 709-714.

Janssen PH. 2006. Identifying the dominant soil bacterial taxa in libraries of 16S rRNA and 16S rRNA genes [J]. Appl. Environ Microbiol, 72 (3): 1719-1728.

Jiao ZQ, Liu XM. 1996. Bacterial identification of molecular biology methods progress [J]. Foreign Medical Health Science, 23 (6): 356-361.

Jones SW, Dobson ME, Francesconi SC, Schoske R, Crawford R. 2005. DNA assays for detection, identification, and individualization of select agent microorganisms [J]. Croat Med J, 46 (4): 522-529.

Kuchel LJ, Franklin CE. 1998. Kidney and cloaca function in the Estuarine Crocodile (Crocodylus porosus) at different salinities: Evidence for solute-linked water uptake [J]. Comp Biochem Physiol, 119 (3): 825-831.

Leaché, AD, Reeder TW. 2002. Molecular systematics of the eastern fence lizard (Sceloporus undulatus): A comparison of parsimony, likelihood, and Bayesian approaches [J]. Syst Biol, 51 (1): 44-68.

May RM. 1991. The role of ecological theory in planning reintroduction [A]. in: Gipps JWH. Beyond captive breeding. Re-introducing captive mammals to the wild [C]. Oxford: Clarendon Press, 145-163.

Mills C. 1999. The wild, wild pest [J]. The Sciences, 3: 10-13.

Miyamoto T, Horie T, Fujiwara T, Fukata T, Sasai K, Baba E. 2000. Lactobacillus flora in the cloaca and vagina of hens and its inhibitory activity against salmonella enteritidis in vitro [J]. Poult Sci, 79 (1): 7-11.

Plowright W. 1988. Viruses transmissible between wild and domestic animals [A]. in: Smith GR, Hearn JP. Reproduction and disease in captive and wild animals [C]. Symposia of the Zoological Society of London. Oxford: Clarendon Press, 175-194.

Qu F. 2006. Advancement in researches of infection by Aeromonas [J]. Infect Dis Info, 19 (1): 22-23.

Rannala B, Yang Z. 1996. Probability distribution of molecular evolution trees: A new method of phylogenetic inference [J]. Mol Evol, 43 (3): 304-311.

Ronquist F, Huelsenbeck JP. 2003. MrBayes 3: Bayesian phylogenetic inference under mixed models [J]. Bioinformatics, 19 (2): 1572-1574.

Shen DX, Feng ZC. 2004. The Progress of Ribosomal RNA gene cluster system in bacteria classification [J]. Medical Recapitulate, 10 (2): 69-71.

Song L, Ning YB, Zhang XY, Shen QC, Zhang GC, Lin SM, Wu HT, Zhao H, Gao G, Feng ZW. 2005. Comparative research on serotype distribution and antimicrobial resistance of Escherichia coli isolates from poultry in different areas of China [J]. Scientia Agricultura Sinica, 38 (7): 1466-1473.

Swofford DL. 1998. PAUP: Phylogenetic Analysis Using Parsimony (and other methods) [M]. Version 4, Sunderland, Massachusetts: Sinauer Associates.

The Group of Bacteriology Classify of the Institute of Microbiology Chinese Academy Science. 1978. Common Method of Determinative Bacteriology [M]. Beijing: Beijing Science Publisher.

Thompson JD, Gibson TJ, Plewniak F, Jeanmougin F, Higgins DG. 1997. The ClustalX windows interface: Flexible strategies for multiple sequence alignment aided by quality analysis tools [J]. Nucleic Acids Res, 24: 4876-4882.

Thorbjarnarson J, Wang XM, Shao M, He LJ, Ding YZ, Wu YL, Scott TM. 2002. Wild population of Chinese alligator approach extinction [J]. Biological Conservation, 103 (1): 93-102.

Vandamme P, Pot B, Gillis M, de Vos P, Kersters K, Swings J. 1996. Polyphasic taxonomy, a consensus approach to bacterial systematics [J]. Microbiological Reviews, 60 (2): 407-438.

Wang DS. 1977. Elementary knowledge of bacteria classification [M]. Beijing: Beijing Science Publisher.

Woodford HM. 2000. Quarantine and Health Screening Protocols for Wildlife Prior to Translocation and Release into the Wild [M]. Switzerland: the IUCN Species Survival Commission's Veterinary Specialist Group and the European Association of Zoo and Wildlife Veterinarians. Paris: the Office International des Epizooties (OIE). U.K.: Care for the Wild.

Woodford MH, Kock RA. 1991. Veterinary considerations in re-introduction and translocation projects [A]. In: Gipps JWH. Beyond Captive Breeding. Re-introducing Captive Mammals to the Wild [C]. Oxford: Clarendon Press, 101-110.

Xia H, Fu WL, Chen M, Huang Q, Zhao M, Zhao YH, Wang F, Luo Y. 2005. The research of rapid DNA extraction from bacteria [J]. Modem Preventive Medicine, 32 (5): 571-573.

Xu YJ, Jiao NZ, Qian LM. 2004. The bacteriological separation diction and identification in water and its deposit [J]. Microbiology, 31 (3): 151-155.

Zhang HY, Li ZG. 2001. Soil bacilli and their sustainable application [J]. Soils, 33(2): 92-97. 